\title{
Preliminary studies on Kumanoa zeylanica (Batrachospermales, Batrachospermaceae) reported from the Western Ghats of India
}

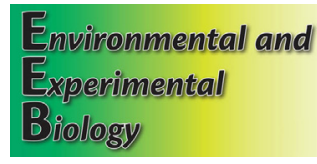

ISSN 2255-9582

\author{
U. Elaya Perumal, R. Sundararaj* \\ Department of Botany, Government Arts College for Men (Autonomous), Affiliated to University of \\ Madras, Nandanam, Chennai 600035, India \\ ${ }^{*}$ Corresponding author, E-mail: sundaralgae@gmail.com
}

UNIVERSITY OF LATVIA

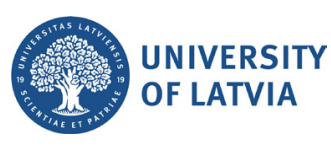

\begin{abstract}
The Western Ghats are among the biodiversity hot spots of India, in which certain regions have been earlier studied for red algal diversity. Keeping this in mind, the Western Ghats and its associated areas were surveyed, which revealed the presence of many fresh water red algae species, including Kumanoa zeylanica from Coorg District of Karnataka State. The alga identified in the present study was earlier reported from the same state but $350 \mathrm{~km}$ (north) towards Belagavi, Karnataka. Morphological data of the current specimen showed more than $95 \%$ similarity with the species K. zeylanica in cluster analysis. Morphological characters like a distinct centrally inserted carposporophyte and contorted carpogonial branches allowed to categorize the alga under the genus Kumnaoa. Morphological and morphometric data on the carposporophyte, carposporangium, trichogyne, spermatia, and fascicle cells are very similar to that of the K. zeylanica reported by Balakrishnan and Chaugule in 1980.
\end{abstract}

Key words: freshwater algae, morphology, red algae, taxonomy.

\section{Introduction}

Red algae (Rhodophyta), which are found outside marine environments, are referred to as freshwater red algae. Even though the majority of the freshwater red algae occur in lotic environments like streams and rivers, a few members have been discovered in lentic environments such as lakes and ponds (Sheath, Hambrock 1990; Sheath et al. 1992), or in some unusual habitats like sloth hairs (Wujek, Timpano 1986), caves (Nagy 1965; Hoffmann 1989), soils (Geitler 1932), and extreme environments like hot water springs (Doemel, Brock 1971). Kumanoa is one of the recently elevated genera of freshwater red algae (Entwisle et al. 2009). It was raised to the generic level from the section of Batrachospermum, the largest genus of freshwater red algae.

Study of members of the family Batrachospermaceae in India started as early as 1862, when Krempelhuber found Batrachospermum vagum (Roth) C. Agardh in South Andaman, India (Krempelhuber 1869). Biswas (1949) described the same species from Meghalaya. Later many species were published under the genus Batrachospermum, in particular, from section Contorta of Batrachospermum (Balakrishnan, Chaugule 1980a; Balakrishnan, Chaugule 1980b; Balakrishnan, Chaugule 1980c; Baluswami, Babu 1999). Nomenclatural changes on all the reported species of section Contorta were performed by Ganesan, West (2013). Batrachospermum zeylanicum Skuja ex Balakrishnan
\& Chaugule was earlier described from the Jog falls of Karnataka state, India (Balakrishnan, Chaugule 1980b). This species was later renamed to Kumanoa zeylanica (Skuja ex Balakrishnan \& Chaugule) Ganesan \& West based on a recent literature survey (Ganesan, West 2013).

Even though the studies on Indian Batrachospermaceae started relatively early in 1862, further contributions to this group are limited. Therefore, the present study was aimed to investigate the Batrachospermaceae members from various parts of southern India. The survey in the Western Ghats resulted in a large number of Batrachospermaceae members, including K. zeylanica from Coorg District, Karnataka, India.

\section{Materials and methods}

\section{Study area}

The present study was carried out on algae collected from Karugunda village, located between Madikeri and the Talacauvery Road, Coorg District of Karnataka State, India (N 12.355620, E 75.650069; Fig. 1). Environmental parameters such as $\mathrm{pH}$ (portable $\mathrm{pH}$ meter), air and water temperature using thermometer, and light intensity (Portable HTC Digital Lux Meter) were recorded randomly from different sites of the stream ( 8 to 10 points within the place where red alga was growing) during the collection 


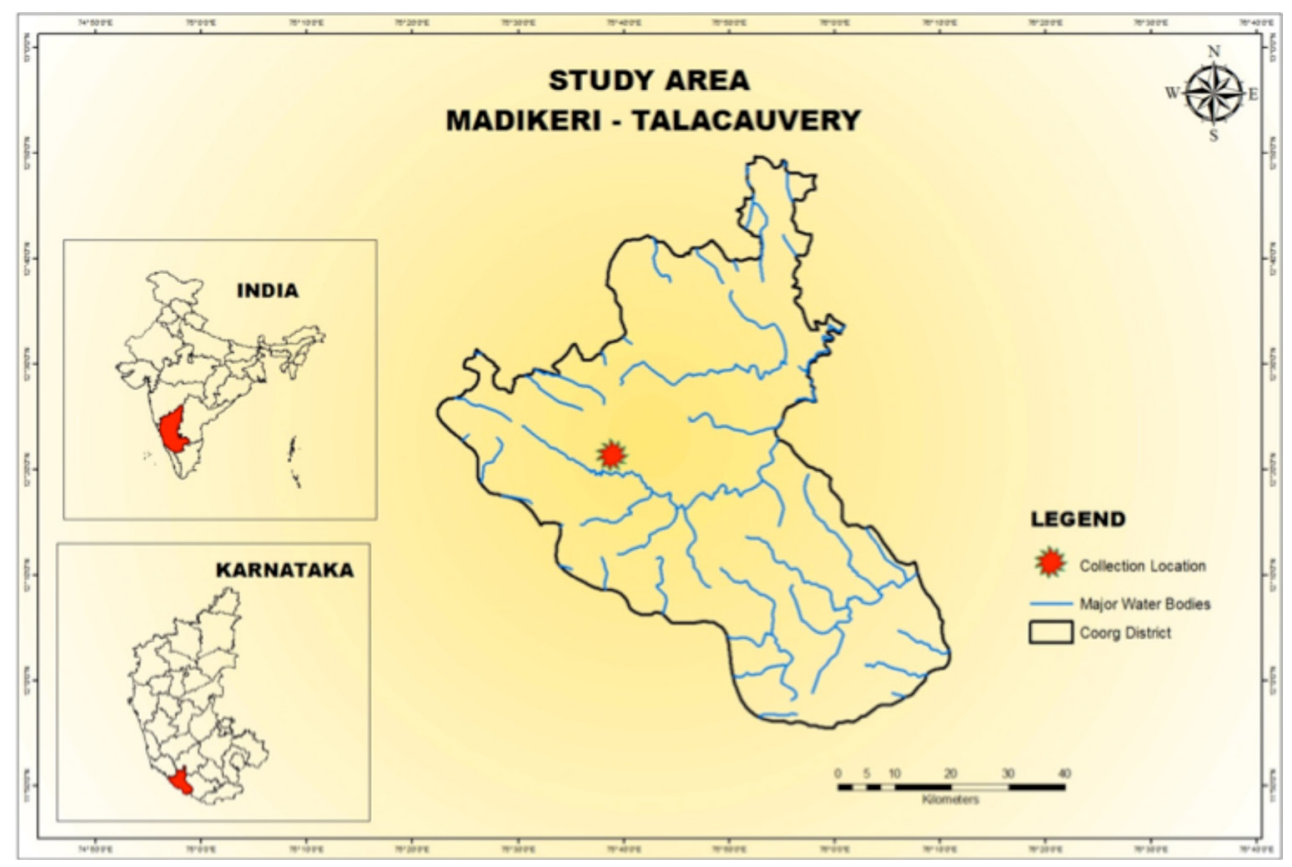

Fig. 1. Map with location of sampling site and the major running water sources in study area.

period. The light intensity was measured by placing the lux meter towards the sky above the algal growing sites. Some environmental factors (climate and disturbances to the habitat) were obtained by physical observation and communicating with local residents.

\section{Collection and preservation}

Samples were collected in plastic containers from the fastflowing streams from January 2015 to September 2016. The samples were preserved by both dry and wet method. In the wet method, the specimen was preserved in $4 \%$ formaldehyde. Herbaria specimens were made in the dry method and tagged as sample No. CRG20. When possible, live samples were brought to the laboratory for further studies.

\section{Observation and identification}

Samples were stained with methylene blue and alcian blue and mounted in $50 \%$ glycerin. Cotton blue-lacto phenol was also used as a staining medium for a few observations. Observation and photography was made at the HoverLabs Research Photomicroscopic Unit. Standard monographs and research articles were used for identification (Balakrishnan, Chaugule 1980a; Desikachary et al 1990; Kumanoa 2002; Entwisle et al. 2009; Salomaki et al. 2014).

\section{Cluster analysis}

Morphology-based cluster analysis was done using Biodiversity Professional Statistical Software (McAleece et al 1997). Every character used was estimated for more than fifteen observations and the mean data was used in the cluster analysis. The morphological data for the already known species were obtained from various literature sources including monographs and the article in which the species were originally described.

\section{Results}

\section{Conditions at study site}

The collected algae specimens were attached to rocks in the fast-flowing stream at depth $0.6 \mathrm{~m}$. The algae were not found growing on other plants or dead material. The collection location was visited once every four-months between 13:00 to15:00 throughout the study period (Table 1). The average values of $\mathrm{pH}$, air and water temperature, and light intensity are given in Table 1.

\section{Description of specimen}

The algae specimens were abundantly growing in the stream, attached to submerged rocks (Fig. 2A) with well-developed rhizoids. The thallus was moderately mucilaginous, brownish-green to dark brown, and 4 to 13 $\mathrm{cm}$ in length (Fig. 2B). Branching was monopodial. The apical portion of the thallus was dome-shaped, with nonprotruding, cylindrical-shaped apical cells (Fig. 1D), which divided transversely to produce axial cells. The length of the apical cell ranged from 5.60 to $7.30 \mu \mathrm{m}$, and the width was 4.75 to $6.20 \mu \mathrm{m}$. The axial cell was 184.00 to $698.20 \mu \mathrm{m}$ in length and 45.70 to $59.50 \mu \mathrm{m}$ in width. Periaxial cells were present at the tip of each axial cell.

The number of periaxial cells were 2 to 8 per axial cell, globular to oval in shape and situated at every nodal region. The periaxial cells were 13.70 to $22.00 \mu \mathrm{m}$ in length and 8.60 to $19.30 \mu \mathrm{m}$ in width, and produced primary fascicles, 
Table 1. Summary of field data for the study period

\begin{tabular}{|c|c|c|c|c|c|c|}
\hline Parameter & $\begin{array}{l}\text { December - } \\
\text { January } 2015\end{array}$ & $\begin{array}{l}\text { April - May } \\
2015\end{array}$ & $\begin{array}{l}\text { August - } \\
\text { September } \\
2015\end{array}$ & $\begin{array}{l}\text { December - } \\
\text { January } 2016\end{array}$ & $\begin{array}{l}\text { April - May } \\
2016\end{array}$ & $\begin{array}{l}\text { August - } \\
\text { September } \\
2016\end{array}$ \\
\hline Availability of alga & $\begin{array}{l}\text { Present with } \\
\text { rich population }\end{array}$ & Alga not found & $\begin{array}{l}\text { Juvenile plants } \\
\text { observed }\end{array}$ & $\begin{array}{l}\text { Present with } \\
\text { rich population }\end{array}$ & Alga not found & $\begin{array}{l}\text { Juvenile plants } \\
\text { observed }\end{array}$ \\
\hline Presence of water & Present & Present & Present & Present & Present & Present \\
\hline $\begin{array}{l}\text { Level of water on } \\
\text { stream }(\mathrm{cm})\end{array}$ & $90 \pm 2$ & $35 \pm 2$ & $100 \pm 2$ & $60 \pm 2$ & $30 \pm 2$ & $120 \pm 2$ \\
\hline Flow & $\begin{array}{l}\text { Moderately fast } \\
\text { flowing }\end{array}$ & Normal flow & Heavy flow & $\begin{array}{l}\text { Moderately fast } \\
\text { flowing }\end{array}$ & Normal flow & Heavy flow \\
\hline Water quality & Clean & Slightly turbid & Slightly turbid & Clean & Slightly turbid & Slightly turbid \\
\hline $\mathrm{pH}$ & $7.2 \pm 0.1$ & $7.8 \pm 0.1$ & $7.5 \pm 0.1$ & $7.5 \pm 0.1$ & $8 \pm 0.1$ & $7.8 \pm 0.1$ \\
\hline Water temperature $\left({ }^{\circ} \mathrm{C}\right)$ & $22 \pm 2$ & $31 \pm 2$ & $24 \pm 2$ & $23 \pm 2$ & $28 \pm 2$ & $23 \pm 2$ \\
\hline Air temperature $\left({ }^{\circ} \mathrm{C}\right)$ & $24 \pm 2$ & $33 \pm 2$ & $27 \pm 2$ & $26 \pm 2$ & $31 \pm 2$ & $25 \pm 2$ \\
\hline $\begin{array}{l}\text { Light intensity ( } \mu \mathrm{mol} \\
\mathrm{m}^{-2} \mathrm{~s}^{-1} \text { ) }\end{array}$ & $222 \pm 5$ & $444 \pm 5$ & $148 \pm 5$ & $296 \pm 5$ & $555 \pm 5$ & $148 \pm 5$ \\
\hline Climate & $\begin{array}{l}\text { Often cloud } \\
\text { forms }\end{array}$ & Hot sun & $\begin{array}{l}\text { Cloudy and } \\
\text { sometimes rain }\end{array}$ & Sun & Hot sun & $\begin{array}{l}\text { Rain (showering } \\
\text { all the time) }\end{array}$ \\
\hline Disturbance & $\begin{array}{l}\text { Washing of } \\
\text { cloths and } \\
\text { bathing }\end{array}$ & $\begin{array}{l}\text { Washing of } \\
\text { cloths and } \\
\text { bathing }\end{array}$ & $\begin{array}{l}\text { No washing, } \\
\text { but bathing } \\
\text { observed }\end{array}$ & $\begin{array}{l}\text { Washing of } \\
\text { cloths and } \\
\text { bathing }\end{array}$ & $\begin{array}{l}\text { Washing of } \\
\text { cloths and } \\
\text { bathing }\end{array}$ & $\begin{array}{l}\text { No washing, but } \\
\text { bathing obse }\end{array}$ \\
\hline $\begin{array}{l}\text { Other plants or algae } \\
\text { on the rocks }\end{array}$ & $\begin{array}{l}\text { Red algae and a } \\
\text { small amount of } \\
\text { bryophytes }\end{array}$ & Bryophytes & Red algae & $\begin{array}{l}\text { Red algae and } \\
\text { bryophytes }\end{array}$ & Bryophytes & Red algae \\
\hline
\end{tabular}

the carpogonial branch, and cortical filaments. From each periaxial cell, 1 to 3 laterals (rarely 4) were seen. Each primary lateral was 6 to 12 cells long, and the cells were cylindrical to ellipsoidal shaped (Fig. 2F), 15.10 to $38.00 \mu \mathrm{m}$ in length and 4.10 to $7.10 \mu \mathrm{m}$ in width. The cells at the tip of the primary fascicles were short, ovoid to elliptical in shape, 15.30 to $19.30 \mu \mathrm{m}$ in length and 5.3 to $7.3 \mu \mathrm{m}$ in width. At the tip of primary fascicle, hairs with a bulbous base (10.10 to $25.70 \mu \mathrm{m}$ length) were rarely seen. Primary glomeruli were globular or disc-shaped and confluent in most of the thallus (Fig. 2C \& E). The diameter of the whorls ranged between 472.70 to $631.30 \mu \mathrm{m}$. The cortical cell originated from the periaxial cells; the periaxial cells had 12.50 to $39.60 \mu \mathrm{m}$ length and 3.40 to $7.00 \mu \mathrm{m}$ width. The secondary laterals initiated from the cortical cells. Secondary fascicles were always absent in the growing region (younger part) of the thallus. The cell shape of the secondary fascicles was similar to that of the primary fascicle. They were less branched compared to primary fascicles. The branches were 4 to 10 long with cells 13.30 to $26.60 \mu \mathrm{m}$ in length and 3.60 to $6.30 \mu \mathrm{m}$ in width.

Generally, plants were monoecious with spermatangia and carpogonia produced on the same thallus. Spermatangia were observed at the apical or subapical position of both primary and secondary laterals (Fig. 3A \& B). They were globular in shape, mostly present in pairs or single with diameter between 5.10 and $8.40 \mu \mathrm{m}$. A single spermatium was produced from each spermatangium, which is released by the apical slit of the persistent spermatangial wall (Fig. 3C). Carpogonial branches were present on the nodal region and initiated from the periaxial cells (Fig. 3D \& F) and rarely from the cortical cell (Fig. 3F; Fig. 4A). The carpogonial branches were 8 to 13 celled, barrel-shaped, spirally coiled and generally 1 to 3 coils were observed. Bracteae were one to three celled and well developed. The carpogonial branch terminated with carpogonium, which was hidden inside the coiled carpogonial branch cells, and only the trichogyne was visible protruding outside the coil (Fig. 3D, E \& F).

The carpogonium was hemispherical to conical (Fig. 3D) in shape and measured 6.70 to $7.30 \mu \mathrm{m}$ in length and 5.80 to $6.40 \mu \mathrm{m}$ in width. The trichogyne was stalked, ellipsoid to obovoid (Fig. 3D \& F) with 12.50 to 24.20 $\mu \mathrm{m}$ length and 7.40 to $12.10 \mu \mathrm{m}$ width. Many spermatia were adhered at the tip of the trichogyne, but only one succeeded and took part in effective fertilization. Soon after fertilization a carposporophyte developed, which was spherically shaped with diameter up to $303.20 \mu \mathrm{m}$ (Fig. 4B). It was centrally inserted in whorls and consisted of tightly packed gonimoblast filaments and carposporangium (Fig. $4 \mathrm{C} \& \mathrm{D})$.

The gonimoblast filaments were branched, 2 to 6 cells long, 13.30 to $25.30 \mu \mathrm{m}$ in length and 4.30 to 7.90 $\mu \mathrm{m}$ in width. Carposporangia were terminal in position 

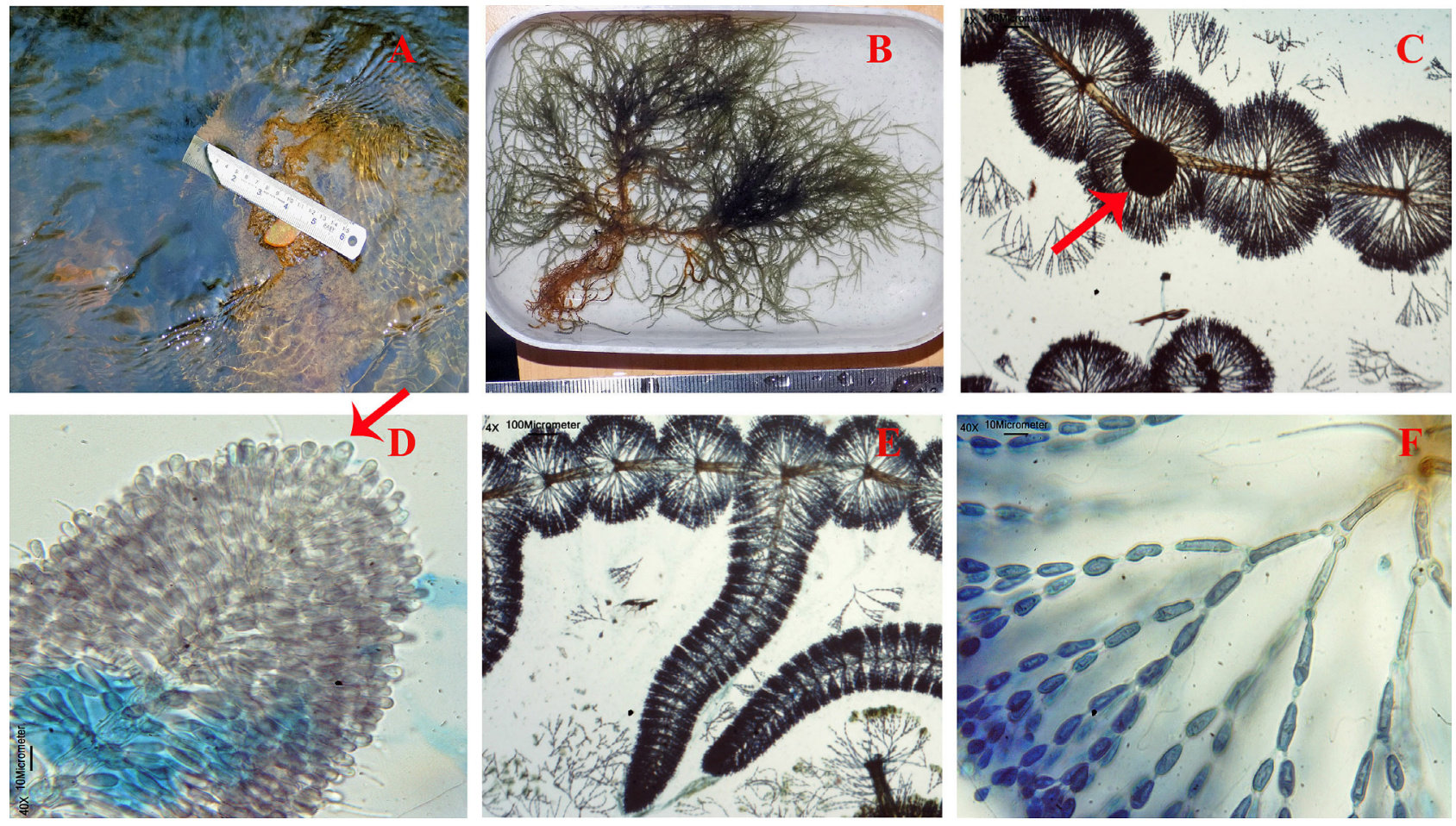

Fig. 2. A, habitat; B, habit; C, primary whorls and carposporophyte (red arrow); D, tip portion with non-protruding apical cell (red arrow); E, enlarged vegetative part showing whorls and branching; F, enlarged view of primary fascicle cells.
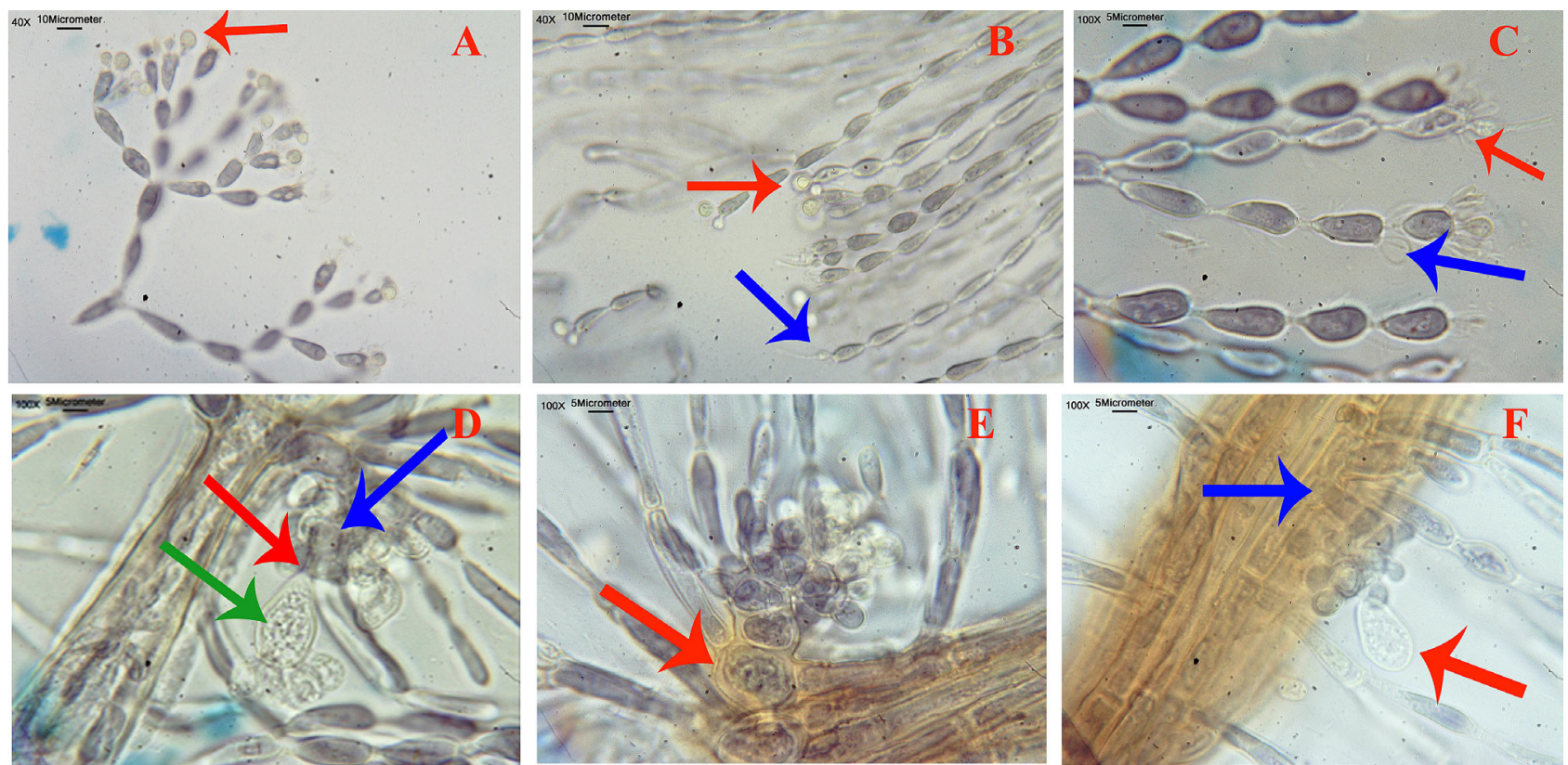

Fig. 3. A, spermatangia on primary fascicle (red arrow); B, spermatangia on secondary fascicle (red arrow), short hair (blue arrow); C, hairs on primary fascicle cells (red arrow), persisting spermatangial wall (blue arrow); D, carpogonial branch with carpogonium (blue arrow), stalked (red arrow) trichogyne (green arrow); E, contorted carpogonial branch initiated from a periaxial cell (red arrow); F, carpogonial branch initiated from cortical filament cells (red arrow), with trichogyne (blue arrow).

and obovoid (Fig. 4C \& D). They produced carpospores, which on germination grew into tetrasporophytes. The carposporangium was 12.50 to $21.60 \mu \mathrm{m}$ in length and 10.80 to $13.50 \mu \mathrm{m}$ in width. In the present study, monospores were not observed in the gametophytic plant. Tetrasporophytic plants were microscopic in nature with prostrate and erect filaments (Fig. 4C \& F). The cells of erect filament cells were 26.20 to $50.20 \mu \mathrm{m}$ in length and 7.6 to $11.60 \mu \mathrm{m}$ in width. The tip of the erect filament had a phialide-like cell, which further divided and formed the elimination cells and the 

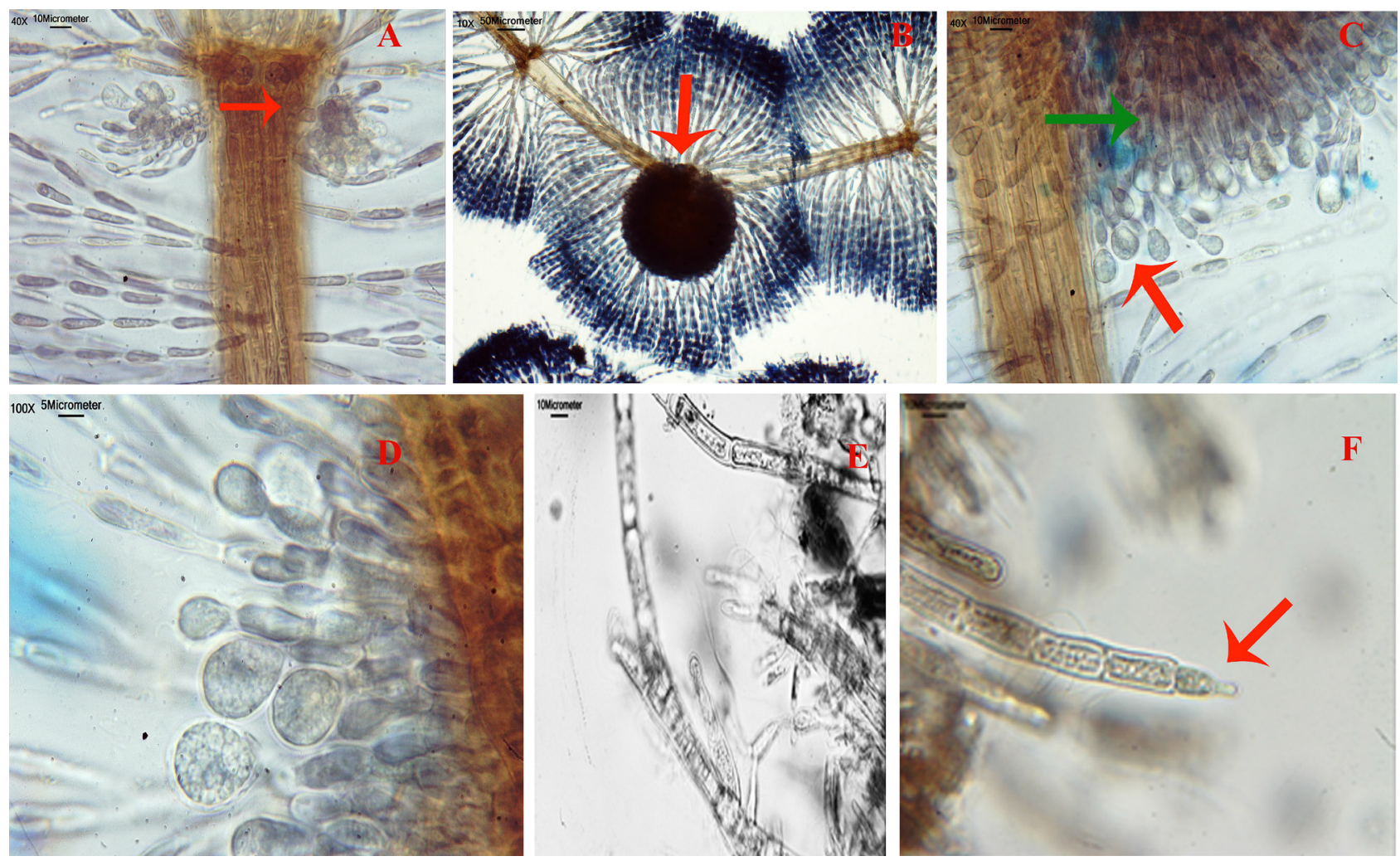

Fig. 4. A, carpogonial branches arising just below the periaxial cell (red arrow) from a cortical cell; B, primary whorl with centrally inserted carposporophyte (red arrow); C, gonimoblast filaments (green arrow) with terminating carposporangium (red arrow); D, enlarged view of carposporangium with a single carpospore; E, tetrasporophyte filaments; F, tetrasporophyte filaments with a phialidelike cell with initial division (red arrow).

gametophyte above that. In this study, phialide-like cells with the first division in erect filaments (Fig. 4F).

\section{Discussion}

ThegenusKumanoa (Batrachospermaceae) hasthefollowing distinct characters by which it can be easily discriminated from the other genera of the Batrachospermaceae (Entwisle et al. 2009; Salomaki et al. 2014). The production of condensed carposporophytes proves that it does not belong to genus Sirodotia or Nothocladus (Kumano 2002). The growth of the gonimoblast filament from the mass of fusion cells called placenta is the characteristic feature of the genus Tuomeya, which is not observed in the present specimens (Kumano 2002). Absence of heterocortication, presence of compactly agglomerated corposporphyte and spirally coiled carpogonial branch confirm that the present specimens belong to genus Kumanoa and not Batrachospermum or Sheathia (Entwisle et al. 2009; Salomaki et al. 2014).

Regarding species, the descriptions agree with all the characters of K. zeylanica [(Skuja ex Balakrishnan et. Chaugule 1980a) Ganesan et. West, 2013]. K. zeylanica has been already reported from the Karnataka State (Balakrishnan, Chaugule 1980a). After more than three decades, the same alga has been recollected from the same state but $350 \mathrm{~km}$ south of the site for the type location. The similarities and dissimilarities between both collections are as follows. The type specimen has $9 \mathrm{~cm}$ length whereas the present specimens (hereafter referred to as CRG 20) have 6 to $13 \mathrm{~cm}$ length. Both were moderately mucilaginous and irregularly branched (Balakrishnan, Chaugule 1980). The plant body was monoecious. Spermatangia were produced terminally on both primary and secondary fascicles, and diameter measured $7.5 \mu \mathrm{m}$ in the type specimen whereas in CRG 20 it was $8.4 \mu \mathrm{m}$. The size of the whorls was 580 $\mu \mathrm{m}$ in the type specimen while for CRG20 it was 616 $\mu \mathrm{m}$ in diameter, which is quite similar. The carpogonial branch consisted of 13 barrel-shaped cells, which is the primary character that confirms the species as $K$. zeylanica (Balakrishnan, Chaugule 1980). Apart from that, the trichogyne, which plays a vital role in identification, was distinctly stalked in both collections, with length $23 \mu \mathrm{m}$ and $24.10 \mu \mathrm{m}$ in the type specimen and CRG 20, respectively. Other notable characters are the nature of the carposporophyte and carposporangia. In the type specimen the shape of the carposporangia was ellipsoid to obovoid, 14 to $22 \mu \mathrm{m}$ in diameter, while in CRG20 it was obovoid and 13.5 to $21.6 \mu \mathrm{m}$ in diameter. The carposporophyte was inserted in the center of the whorls and generally remained single with diameter up to $303 \mu \mathrm{m}$ in both collections. In addition to the above characters, the presence of the 


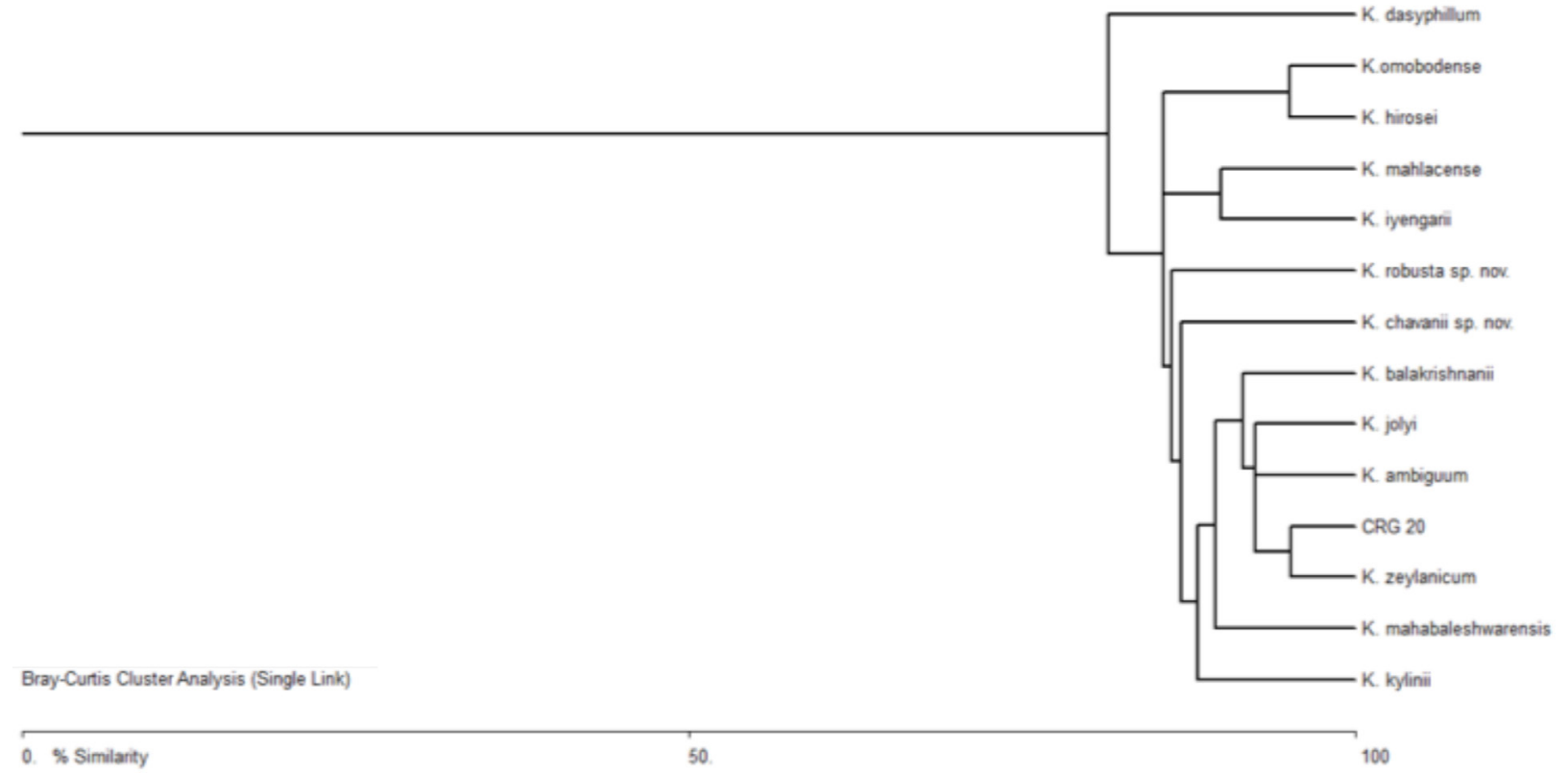

Fig. 5. Cluster diagram showing the similarity between K. zeylanica and CRG 20.

carpogonial branch at the internodal region was also observed, i.e., the carpogonial branch was produced from the cortical filament cells. Further detailed study on the type specimen will justify this character. This character occurs in Kumanoa jolyi [(Nechi) Nechi \& M.L. Vis] Nechi and Vis (2012), but this species has more dissimilarities than the K. zeylanica: obconic, pear-shaped, barrel-shaped or spherical whorls; curved primary fascicles with cellstoreys up to 20; abundant secondary fascicle covering entire internode; cylindrical unstalked trichogyne; 6 to 10 celled carpogonial branch; carposporophyte up to 450 $\mu \mathrm{m}$ in diameter; carposporangia with $14 \mu \mathrm{m}$ length and 11 $\mu \mathrm{m}$ width. These are the main features that confirm that CRG20 is K. zeylanica, not K. jolyi. The morpho-taxonomic cladogram developed using Biodiversity Pro software also supports this result. The similarities between $K$. zeylanica and CRG 20 are maximum; hence both arose from sister clades (Fig. 5). In the present specimen, the tetrasporophytes had phialide-like cells, which produced the elimination cells and gametophyte (Balakrishnan, Chaugule 1975).

Seasonal variations are environmental factors that mostly influence the algal communities (Necchi-Júnior, Pascoaloto 1993). Variations are associated with rainfall, turbidity and water flow are the most important factors that affect the algal community of particular regions (Necchi-Júnior et al. 1991; Necchi-Júnior, Pascoaloto, 1993). The repeated visits to the sampling site showed that the specimens were present only in the monsoon, postmonsoon and winter seasons and absent in summer, which is a common feature of the Batrachospermaceae members. Most of the members of Batrachospermaceae have been collected during the monsoon and winter periods only (Branco et. al. 2008).

\section{Conclusions}

The Western Ghats of India is found to be a common location for members of fresh water red algae. A detailed morphometric analysis of collections from the Karnataka State (Western Ghats region) confirmed that the alga is Kumanoa zeylanica, which has been already reported from the same state. The study revealed that this alga is present in other places of Western Ghats and further detailed study on the Western Ghats is needed to examine the diversity of this alga. The present collections were collected from a fast-flowing forest stream. Even though the stream has water throughout the year, the alga was not observed during summer, which shows that this season is not ideal for growth. The temperature of the water and atmosphere is high compared to other seasons, and the high light intensity is also an influencing factor. The $\mathrm{pH}$ of the water is also slightly high during summer, which can play a significant role in algal growth. The best time to collect this alga is between November and January, but this depends on the beginning and end of the rainy season. The description of $K$. zeylanica has been updated with the presence of the carpogonial branch in the intermodal region.

\section{Acknowledgements}

We thank Mr. U. Sivaraj, and Mr. U. Ramachandran for their financial support for the research scholar. We express our gratitude towards Prof. B.B. Chaugule, Former Head Department of Botany, Savitribai Phule Pune University, Pune, for his continuous support and research knowledge sharing in fresh water red algae. 


\section{References}

Balakrishnan M.S., Chaugule B.B. 1975. Elimination cells in the Batrachospermaceae. Curr. Sci. 44: 436-437.

Balakrishnan M.S., Chaugule B.B. 1980a. Indian Batrachospermaceae. In: Desikachary T.V., Raja Rao T.N. (eds) Taxonomy of Algae. University of Madras, Madras, pp. 223-248.

Balakrishnan M.S., Chaugule B.B. 1980b. Indian Batrachospermaceae. In: Taxonomy of Algae. Papers presented at the International Symposium on Taxonomy of Algae held at the Centre of Advanced Study in Botany University of Madras, December 9-16, 1974. (Desikachary, T.V. \& Raja Rao, V.N Eds), pp. 291-300. Madras: University of Madras.

Baluswami M., Babu M. 1999. The structure and reproduction of Batrachospermum umamaheswararaoi sp.nov. In Subbarangiah G. (ed) Recent Trends in Algal Research. Andhra University, Waltair, pp. 245-254.

Biswas K. 1949. Common fresh and brackish water algal flora of India and Burma. Rec. Bot. Surv. India 15: 1.

Branco C.C.Z., Krupek R.A., Peres C.K. 2008. Seasonality of macroalgal communities in a subtropical drainage basin in Paraná state, southern Brazil. Braz. J. Biol. 68: 741-749.

Chaugule B.B. 1980. Morphology and life history of a new species of Batrachospermum from Kas (Maharashtra). Maharashtra Viswa Mahavidyalaya Patrika 15: 1-8.

Desikachary T.V., Krishnamurthy V., Balakrishnan M.S. 1990. Rhodophyta. Part IIA. Madras Science Foundation, Madras, $279 \mathrm{p}$.

Doemel W.N., Brock T.D. 1971. The physiological ecology of Cyanidium caldarium. J. Gen. Microbiol. 67: 17-32.

Entwisle T.J., Vis M.L., Chiasson W.B., Necchi O.Jr., Sherwood A.R. 2009. Systematics of the Batrachospermales (Rhodophyta): a synthesis. J. Phycol. 45: 704-715.

Geitler L. 1932. Porphyridium sordidum n. sp. eine neue Süßwasserbangiale. Archiv für Protistenk 76: 595-604.

Guiry M.D., Guiry G.M. 2016. AlgaeBase. World-wide electronic publication, National University of Ireland, Galway. http:// www.algaebase.org; searched on 28 October 2016.

Harvey W.H. 1858. Nereis boreali-americana... Part III. Chlorospermeae. Smithsonian Contributions to Knowledge
10: $1-140$.

Hoffmann L. 1989. Algae of terrestrial habitats. Bot. Rev. 55: $77-$ 105.

Krempelhuber A.V. 1869. Beitrag zur Algen flora Indienes von Dr. G.V. Martens in Stuttgart. Flora 52: 233.

Kumano S., Bowden-Kerby W.A. 1986. Studies of the freshwater Rhodophyta of Micronesia I. Six new species of Batrachospermum Roth. Jap. J. Phycol. 34: 107-128.

Kumano S. 1986. Studies on freshwater red algae of Malaysia VI. Morphology of Batrachospermum gibberosum (Kumano), comb. nov. Jap. J. Phycol. 34: 19-24.

Kumano S. 2002. Freshwater Red Algae of the World. Biopress, Bristol, $375 \mathrm{p}$.

Kylin H. 1912. Studien über die Schwedischen Arten der Gattungen Batrachospermum Roth und Sirodotia nov. gen. Nova acta Regiae Societatis Scientiarum Upsaliensis. Ser. IV 3: $1-40$.

McAleece, N., Gage, J.D.G., Lambshead, P.J.D., Paterson, G.L.J. 1997. BioDiversity Professional statistics analysis software. Jointly developed by the Scottish Association for Marine Science and the Natural History Museum London.

Nagy J.P. 1965. Preliminary note on the algae of Crystal cave, Kentucky. Int. J. Speleol. 1: 479-490.

Ratnasabapathy M., Kumano S. 1982. Studies on freshwater red algae of Malaysia II. Three species of Batrachospermum from Sungai Gombak and Sungai Pusu, Selangor, West Malaysia. Jap. J. Phycol. 30: 119-124.

Roth A.W. 1797. Bemerkungen über das Studium der cryptogamischen Wassergewächse. Hannover.

Salomaki E.D., Kwandrans J., Eloranta P., Vis M.L. 2014. Molecular and morphological evidence for Sheathia gen. nov. (Batrachospermales, Rhodophyta) and three new species. J. Phycol. 50: 526-542.

Shi Z.-X. 1994. Two new species of the genus Batrachospermum (Rhodophyta) in China. Acta Phytotaxon. Sin. 32: 275-280.

Skuja H. 1934. Untersuchungen über die Rhodophyceen des Sußwassers. Beihefte zum Botanische Centralblatt 52: 173-192.

Wujek D.E., Timpano P. 1986. Rufusia (Porphyridiales, Phragmonemataceae), a new red algae from sloth hair. Brsenesia 26: 163-168. 